\title{
THE RED DRESS
}

Sylvia Townsend Warner

No talisman but my heart.

No armour but my blood.

I was in my dream

When my kind enemy came, Saying, Put on your red

Dress for this last night, For this last time.

Outmoded was the dress

And ill to fasten on:

Cares and sighing had

Me with dull fat overlaid, But at last it was done, And brilliant in the glass My image stood.

Her lips were close to mine When a summons bid. Then as I left the room She with slow stepping from The mirror disappeared; And I went all alone Downstairs to my doom.

Life and Letters Today No. 23, July 1939. 
Warner's stories are 'noteworthy for their graceful, witty prose and their tough, uncompromising intelligence'.

Jonathan Yardley

Sylvia Townsend Warner: a 'copious, elegant and witty writer'.

Frank Kermode

'Miss Warner's genius is an uncannily equable openness to human data, and beneath her refined witchery lies a strange freshness one can only call, in praise, primitive'.

John Updike 